\title{
Insulinoma: Spectrum of Clinicopathological Features in a Tertiary Center
}

\author{
İnsülinoma: Üçüncül Bir Merkezdeki Klinikopatolojik Özelliklerin Spektrumu
}

\begin{abstract}
(D) Nooshin Shirzad1,2, (D) Pooria Ahmadi1, (D) Reza Shahsiah³, (D) Mahboobeh Hemmatabadi1
${ }^{1}$ Tehran University of Medical Sciences Vali-Asr Hospital, Imam Khomeini Complex Hospital, Endocrinology and Metabolism Research Center, Department of Endocrinology, Tehran, Iranian

${ }^{2}$ Tehran University of Medical Sciences, Endocrinology and Metabolism Clinical Sciences Institute, Endocrinology and Metabolism Research Center, Tehran, Iranian

3Tehran University of Medical Sciences, İmam Khomeini Complex Hospital, Department of Pathology, Tehran, Iranian
\end{abstract}

\begin{abstract}
Introduction: Insulinoma is the most common functional neuroendocrine tumor of the pancreas. There are different methods for the preoperative localization of insulinoma, such as Computed Tomography (CT) scan, Magnetic Resonance Imaging and Endoscopic Ultra Sonography (EUS). In this study, we report on the clinicopathological features of insulinoma in 43 patients.
\end{abstract}

Methods: The hospital records of 43 patients with suspicion of insulinoma based on biochemical diagnostic criteria, referred to Imam Khomeini Complex Hospital, Tehran, Iran between 2006 and 2016, were reviewed retrospectively.

Results: Of the 43 studied patients, 28 were female. The mean age of the patients was $45.4 \pm 13.3$ years. The most frequent clinical presentation of insulinoma was neurogenic and neuroglycopenic symptoms (81.4\%). Mean glucose, insulin, and C-peptide in patients with hypoglycemic crisis were $39.13 \pm 13.15 \mathrm{mg} / \mathrm{dL}, \quad 32.15 \pm 32.53 \mu \mathrm{UI} / \mathrm{mL}$, and $4.77 \pm 2.88$ $\mathrm{ng} / \mathrm{mL}$, respectively. Mean tumor size was $2.13 \pm 1.22 \mathrm{~cm}$. The most common site of insulinoma was the tail of the pancreas. Surgery was the treatment of choice and performed in 31 patients. Of 21 tumors studied microscopically, 7 were invasive.

Conclusion: In non-diabetic patients with manifestations of hypoglycemia, a diagnosis of insulinoma should be considered. During the past decade, the diagnostic delay for insulinoma has been reduced in our country by improving imaging technologies. EUS and CT scan are the best modalities for localization and size measurement of insulinoma. Tumor size has decreased compared with previous decades, probably due to a reduced delay in diagnosis.

Keywords: Insulinoma, hypoglycemia, neoplasm, pancreas

\section{öZ}

Amaç: İnsülinoma pankreasın en sık görülen fonksiyonel nöroendokrin tümörüdür. Bilgisayarlı Tomografi (BT) tarama, Manyetik Rezonans Görüntüleme ve Endoskopik Ultrasonografi (EUS) gibi insülinomaların preoperatif lokalizasyonu için farklı yöntemler vardır. Bu çalışmada 43 hastada insülinomun klinikopatolojik özellikleri sunulmaktadır.

Yöntemler: 2006-2016 yılları arasında Tahran, İran'da İmam Humeyni Kompleks Hastanesi'ne atıfta bulunulan biyokimyasal tanı kriterlerine göre insülinoma şüphesi olan 43 hastanın retrospektif olarak hastane kayıtları incelendi.

Bulgular: Çalışılan 43 hastanın 28'i kadındı. Hastaların ortalama yaşı 45,4 $\pm 13,3$ idi. İnsülinomun en klinik görünümü nörojenik ve nöroglikopenik semptomlardı $(\% 81,4)$. Hipoglisemik kriz hastalarında ortalama glikoz, insülin ve C-peptit sırasıyla; $39,13 \pm 13,15 \mathrm{mg} / \mathrm{dL}, 32,15 \pm 32,53 \mu \mathrm{UI} / \mathrm{mL}$ ve $4,77 \pm 2,88 \mathrm{ng} /$ $\mathrm{mL}$ idi. Ortalama tümör boyutu $2,13 \pm 1,22 \mathrm{~cm}$ idi. En yaygın insülinoma bölgesi pankreas kuyruğuydu. Cerrahi tedavi tercih edildi ve 31 hastaya uygulandı. Mikroskobik incelemeli 21 tümörden 7’si invazivdi.

Sonuç: Hipoglisemi belirtileri olan diyabetik olmayan hastalarda insülinoma tanısı düşünülmelidir. Son on yılda, görüntüleme teknolojilerini geliștirerek ülkemizde insülinomun tanısal gecikmesi azalmıştır. EUS ve BT taraması insülinoma lokalizasyonu ve boyut ölçümü için en iyi yöntemlerdir. Muhtemelen tanıdaki gecikmenin azalması nedeniyle tümör boyutu önceki on yıllara göre azalmıştır.

Anahtar Kelimeler: Insülinoma, hipoglisemi, neoplazm, pankreas 


\section{Introduction}

Pancreatic cancers may arise from exocrine or neuroendocrine cells of the pancreas. Most pancreatic cancers are exocrine cancers, and neuroendocrine tumors are rare pancreatic masses that originate from the islets of Langerhans (1). Neuroendocrine neoplasms are the second most common pancreatic tumors and account for $1 \%-2 \%$ of all pancreatic neoplasms (2). In the recent decade, the incidence of pancreatic neuroendocrine neoplasms ( $\mathrm{pNEN}$ ) has increased significantly and reached $1 / 100,000$ population per year $(3,4)$. This increased rate may be due to the improved diagnostic imaging techniques as well as increased knowledge and awareness of physicians about these neoplasms (5). The age range of most patients with pNEN is from 30 to 60 years, and there is no gender difference $(3,4)$.

pNENs are divided into two groups: functional and non-functional. As non-functional tumors have no symptoms, they are usually diagnosed at a more advanced stage of disease than functional tumors such as insulinoma.

Insulinoma is a functional pNEN and the most common type (6). Insulinoma is the main cause of hypoglycemia due to endogenous hyperinsulinemia. Insulinomas are benign in $90 \%$ of cases (7).

Insulinoma is a rare tumor with an incidence rate of $0.15 \%-0.4 \%$ (8). It represent $1 \%-2 \%$ of all pancreatic neoplasms (9) and is the cause of $70 \%-75 \%$ of hyperinsulinemia cases (8). However, the prevalence rate is unknown, as the incidence rate in autopsy reports is higher (0.8\%-10\%) $(10,11)$.

The diagnostic hallmark of insulinoma is Whipple's triad, which includes the simultaneous presence of three symptoms of hypoglycemia, compatible adrenergic (neurogenic) and/or neuroglycopenic signs, and symptom relief upon administration of glucose (8).

Insulinoma in most cases is sporadic; however, in 4\%-10\% of cases, it may be associated with multiple endocrine neoplasia type-1 (MEN1) syndrome, which tends more to be malignant (12).

The main goal of this study was to present clinicopathological characteristics of insulinoma in a series of 43 patients.

\section{Methods}

In a retrospective study, the hospital records of all patients with insulinoma tumors, referred to Imam Khomeini Hospital (a tertiary center), Tehran, Iran from 2006 to 2016, were reviewed.

In this study, all patients with clinical manifestations of hypoglycemia and positive biochemical tests results including low blood sugar and high insulin and C-peptide levels, as well as those with hypoglycemic symptoms such as palpitation, tremor, sweating, and a histological report of insulinoma, even without any information about laboratory results (including low blood sugar and high insulin and C-peptide levels), were included in the study.

Patients with a positive sulfonylurea test, those with positive biochemical test results but different histology (other than insulinoma), and those with a known history of treated insulinoma in previous years that were referred due to liver metastasis, were excluded from the study.
Patients' information, including personal information, clinical symptoms, laboratory tests results, imaging and pathology reports, and treatment modality, was recorded in a questionnaire.

The study protocol was approved by the Ethics Committee at Imam Khomeini Hospital, and the study was conducted according to the Helsinki declaration (approval number: IR.TUMS.IKHC.REC.1396.3105, date: 07.08.2017).

\section{Statistical Analysis}

Data were presented as mean and standard deviation for numerical data and number and percentage for categorical data. Independent Samples t-tests and chi-square tests were used to compare numerical data with a normal distribution and categorical data, respectively. For comparison of more than two groups, analysis of variance and the Kruskal-Wallis test were used for data with and without a normal distribution, respectively. Data analysis was performed using SPSS software version 20.00 for Windows, and results were considered significant at $p<0.05$.

\section{Results}

\section{Demographics}

Finally, 43 patients with insulinoma were included in the study. Of them, 38 were selected on the basis of positive laboratory evidence of insulinoma and 5 on the basis of a pathological report of insulinoma.

The patients' demographic characteristics are presented in Table 1. Of 43 patients, 28 were aged below 50 years and 15 above 50 years.

\section{Clinical Presentation}

The number of hypoglycemic crisis was registered in 25 patients. Of them, the number of crises varied from 4 crises in a day and 1 in a month, with a mean of 18 crises in a month. Other information regarding clinical presentation, symptoms, and biochemical parameters is shown in Table 1.

Weight changes were registered in 20 patients. Of them, 2 patients had no change in weight and 18 had variable changes in weight from $10 \mathrm{~kg}$ weight loss to $31 \mathrm{~kg}$ weight gain (mean of $7 \mathrm{~kg}$ weight gain).

There was no significant association between age (below and above 50 years) and changes in weight ( $7.07 \pm 3.00$ vs $6.8 \pm 14.61$, respectively) or between the number of crises in a week $(4.90 \pm 6.8$ vs $3.00 \pm 2.09$, respectively) and the duration of the 72-hour fasting test (11.58 \pm 8.37 vs $12.91 \pm 19.29)(p>0.05)$. Also, no significant association was found between age (below and above 50 years) and the mean glucose level during a hypoglycemic crisis ( $40.25 \pm 14.20$ vs $37.80 \pm 17.46$, respectively) $(p>0.05)$.

The mean serum insulin level during a hypoglycemic crisis in patients aged less than 50 years was significantly higher than in those aged above 50 years (39.32 \pm 37.45 and $17.80 \pm 9.69$, respectively) $(p<0.05)$. However, serum C-peptide levels were not significantly different between the two age groups $(5.22 \pm 3.37$ in patients below 50 years and $3.87 \pm 1.19$ in those above 50 years old).

There was a significant correlation between the number of crises in week and weight changes $(r=0.62, p=0.03)$. Also, a significant direct 
correlation was found between the number of crises in a week and the time interval between disease onset and referral $(r=0.50, p=0.01)$.

There was no significant correlation between the number of crises in a week and the duration of the fasting test $(r=0.44, p=0.23)$. In addition, no significant correlation was observed between weight changes and the time interval from disease onset to referral $(r=0.07, p=0.81)$. There was a significant correlation between insulin and the C-peptide level at the end of the fasting test $(r=0.64, p<0.001)$.

\section{Tumor Size and Location}

Of 43 patients, tumor size was determined in 21 cases based on the pathology report, and the accuracy of size measurement by computed tomography (CT) scan and endoscopic ultrasonography (EUS) was compared with the size reported by pathology as the gold standard. According to this analysis, correlation of the size reported by pathology was more compatible with the CT report than the EUS report in these 21 cases. In other cases without a pathology report, tumor size was considered according to the CT scan report, and in those without a CT scan report, the size reported by EUS was considered as the tumor size. Therefore, 31 of 43 patients had a definite tumor size: in 21 patients according to the pathology report, in 6 based on the CT scan report, and in 4 based on EUS. The mean tumor size available in 21 patients according to the pathology report was $2.13 \pm 1.22 \mathrm{~cm}(0.6-5.5 \mathrm{~cm})$.

The tumor location of was available in 25 patients (based on the pathology report or surgery report): 10 in the head, 4 in the body, and 11 in the tail of the pancreas.

Regarding imaging, in 35 patients, EUS had been performed, and the related findings are shown in Figure 1. In three patients, tumor size had not been reported. The mean tumor size in 24 patients with tumor size reported by EUS was $1.67 \pm 0.60 \mathrm{~cm}(0.6-3.2 \mathrm{~cm})$.

Another imaging study was CT scan, which had been performed for 35 patients. Tumor location by CT scan is depicted in Figure 2. In two cases, tumor size had not been reported. Mean tumor size according to CT scan, available for 17 patients, was $1.7 \pm 0.86 \mathrm{~cm}(0.5-3.9 \mathrm{~cm})$.

Mean tumor size for the head, body, and tail was $2.06 \pm 1.12,1.22 \pm 0.69$, and $2.13 \pm 1.48 \mathrm{~cm}$, respectively, and tail tumors were larger.

By using CT scan and EUS 77.5\% (31 cases) of insulinoma tumors were localized. Of 40 patients with available recorded imaging reports, the tumor was not localized in 9 cases (22.5\%).

In 25 cases with a pathology report of the tumor location, CT scan imaging had been performed for 22 cases. For localization of the tumor by considering pathological study as the gold standard, the sensitivity of

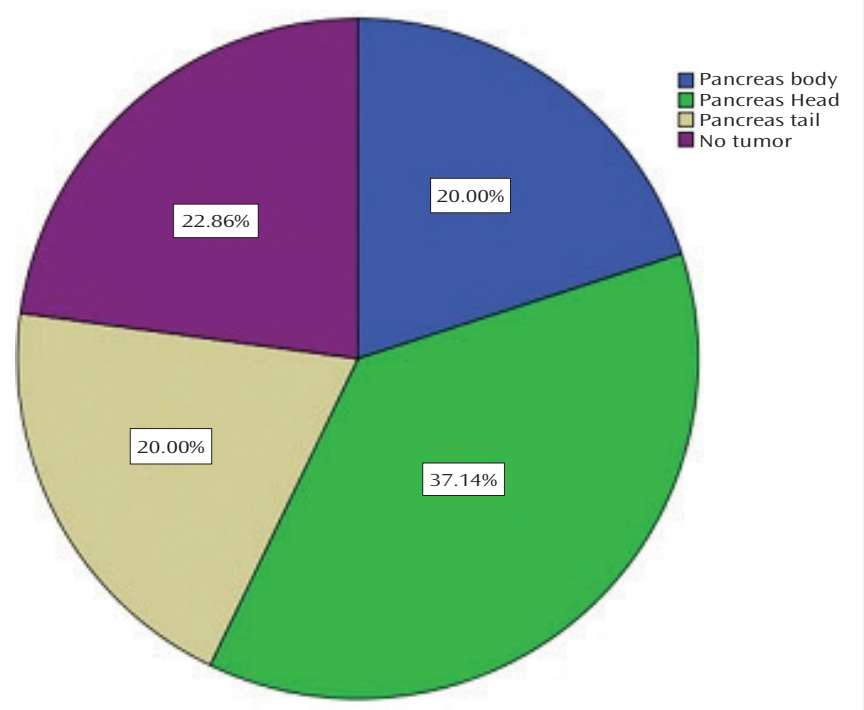

Figure 1. Tumor location by EUS

EUS: Endoscopic ultrasonography

Table 1. Demographic, clinical, and paraclinical characteristics of 43 patients with insulinoma

\begin{tabular}{|c|c|c|}
\hline Variable & n & Value \\
\hline Age (mean \pm SD) & 43 & $45.4 \pm 13.3(21-70)$ years \\
\hline Gender, $n(\%)$ & 43 & F 28 (65.11), M 15 (34.89) \\
\hline \multicolumn{3}{|l|}{ Clinical presentation } \\
\hline Neurogenic symptoms, $\mathrm{n}(\%)$ & \multirow{3}{*}{43} & $4(9.30)$ \\
\hline Neuroglycopenic symptoms, n (\%) & & $4(9.30)$ \\
\hline Both symptoms, n (\%) & & $35(81.4)$ \\
\hline \multicolumn{3}{|l|}{ Symptoms in } \\
\hline Fasting, $n(\%)$ & \multirow{3}{*}{43} & $38(88.40)$ \\
\hline Postprandial, n (\%) & & $1(2.30)$ \\
\hline Both conditions, $\mathrm{n}(\%)$ & & $4(9.30)$ \\
\hline Interval between onset of symptoms and referral, average (ranges) & 43 & 2 years ( 1 month- 10 years) \\
\hline Glucose level in hypoglycemic crisis, mean \pm SD (range) & 40 & $39.3 \pm 13.15 \mathrm{mg} / \mathrm{dL}(10-74 \mathrm{mg} / \mathrm{dL})$ \\
\hline C-peptide level in hypoglycemic crisis mean \pm SD (range) & 39 & $4.77 \pm 2.88 \mathrm{ng} / \mathrm{mL}(1.36-18 \mathrm{ng} / \mathrm{mL})$ \\
\hline Insulin level in hypoglycemic crisis, mean \pm SD (range) & 39 & $32.15 \pm 32.53 \mu \mathrm{UI} / \mathrm{mL}(5.6-154 \mu \mathrm{UI} / \mathrm{mL})$ \\
\hline Duration of fasting test, mean (range) & 18 & $12(3-30)$ hours \\
\hline
\end{tabular}

SD: Standard deviation, F: female, M: male 
CT scan was $68.18 \%$, and its positive predictive value (PPV) was $72.22 \%$. According to the tumor location, sensitivity and PPV of CT scan for the head, body, and tail tumor was 55.55\% and 100\%, 100\% and 75\%, and $66.66 \%$ and $83.33 \%$, respectively.

EUS had been performed for 23 patients. Sensitivity and PPV of EUS for localization of the tumor was $95.65 \%$ and $77.27 \%$, respectively. According to the tumor location, the sensitivity and PPV of EUS for pancreas head, body, and tail tumors was $100 \%$ and $87.5 \%, 100 \%$ and $75 \%$, and $90.90 \%$ and $70 \%$, respectively.

Regarding tumor size measurement by considering histological examination as the gold standard, there was a significant correlation between tumor size reported by EUS and histology as well as between CT scan and histology ( $r=0.837$ and $r=0.948$ for EUS and CT scan, respectively). Correlation between $\mathrm{CT}$ scan and histology was stronger than between EUS and histology and the accuracy of CT scan in the estimation of tumor size was higher than that of EUS.

Among the studied patients, there were two cases of MEN1 syndrome. As the first one was a known case of MEN1 and had died in intensive care unit after surgery, this case was excluded from the study.

There was no significant association between age (below and above 50) and tumor size (1.97 \pm 1.14 vs $1.64 \pm 1.19$, respectively).

No significant association was found between weight change, the mean glucose level during hypoglycemia, duration of the fasting test, and tumor size (less than $2 \mathrm{~cm}$ and greater than $2 \mathrm{~cm}$ ).

Glucose and insulin levels at the end of the fasting test were not different between those with tumors less and greater than $2 \mathrm{~cm}(32.89 \pm 13.98$ vs $43.55 \pm 16.43 \mathrm{mg} / \mathrm{dL}$ for glucose and $26.53 \pm 20$ vs $46.38 \pm 43.91$ for insulin level, respectively).

The number of hypoglycemic crises per week in patients with tumor sizes greater than $2 \mathrm{~cm}$ was significantly higher than those with tumor sizes less than $2 \mathrm{~cm}(9.25 \pm 11.98$ vs $2.95 \pm 2.45)$. Also, the C-peptide level

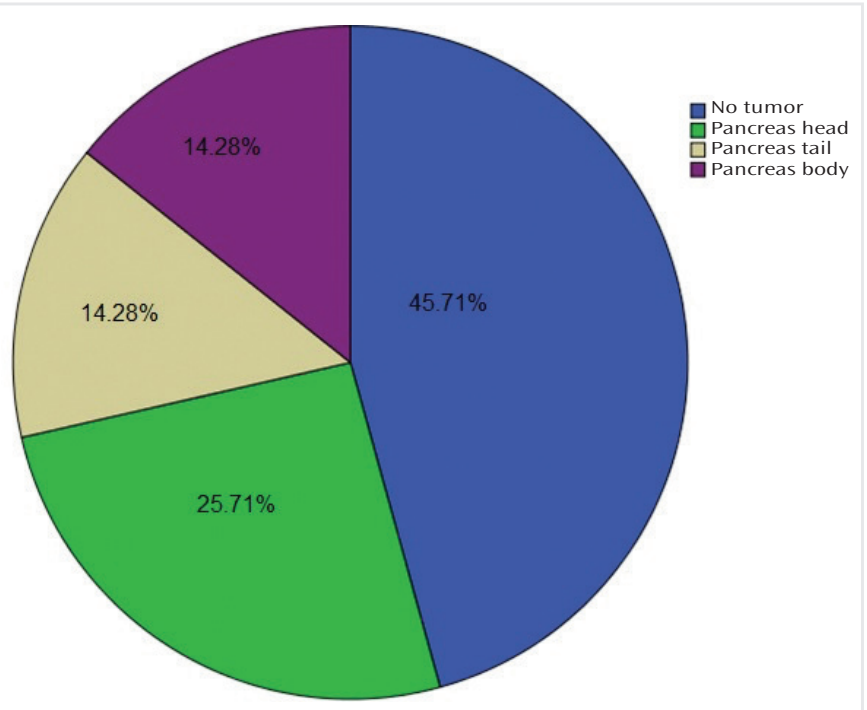

Figure 2. Tumor location by CT scan

CT: Computed tomography during hypoglycemia was higher in tumors greater than $2 \mathrm{~cm}$ than in tumors less than $2 \mathrm{~cm}(6.36 \pm 4.73$ vs $4.01 \pm 1.41)$.

There was no significant difference in the interval from the onset of disease to referral between those with a tumor size greater and less than $2 \mathrm{~cm}$.

\section{Treatment}

Treatment had been recorded in 39 of 43 patients. Of 39 patients with available data, 31 (79.49\%) underwent operation and 8 (20.51\%) received medical treatment.

\section{Tumor Pathology}

Among 43 patients, insulinoma had been reported as a pathological condition in 21cases. Pathological slides were re-studied, and specific staining was performed in available cases. Pathological characteristics are shown in Table 2.

There was a significant difference in mitotic activity between pancreatic head, body, and tail tumors.

Regarding mitotic activity and tumor size in available data in 21 cases, all 11 tumors sized lesser than $2 \mathrm{~cm}$ were grade 1 and of 10 tumors sized greater than $2 \mathrm{~cm}, 6$ were grade 1,3 grade 2 , and one was grade 3. There was a significant association between tumor size and mitotic activity $(p=0.018)$.

There was no significant association between mitotic activity and tumor invasion.

Tumor invasion was seen in $33.3 \%$ of patients (7 cases). The highest rate of invasion was seen in pancreatic tail insulinomas (50\% in comparison to $33 \%$ in the body and $22.2 \%$ in the head). In microscopic evaluation, malignant insulinoma with invasion to adjacent tissues was identified in 7 of 21 studied cases (33.33\%) and among those with malignant

\section{Table 2. Pathological characteristics of studied patients with} insulinoma

\begin{tabular}{|c|c|c|}
\hline Variable & $\mathbf{n}$ & Value \\
\hline \multicolumn{3}{|l|}{ Microscopic pattern } \\
\hline Solid, n (\%) & \multirow{3}{*}{19} & $8(42.10)$ \\
\hline Gyriform, n (\%) & & $7(36.84)$ \\
\hline Other patterns, n (\%) & & $4(21.05)$ \\
\hline \multicolumn{3}{|l|}{ Mitotic activity } \\
\hline Grade 1, n (\%) & \multirow{3}{*}{21} & $17(80.95)$ \\
\hline Grade 2, n (\%) & & $3(14.28)$ \\
\hline Grade 3, n (\%) & & $1(4.76)$ \\
\hline \multicolumn{3}{|l|}{ Amyloid rate } \\
\hline No & \multirow{3}{*}{15} & $10(66.66)$ \\
\hline Low & & $3(20.00)$ \\
\hline High & & $2(13.33)$ \\
\hline \multicolumn{3}{|l|}{ Cell cytoplasm } \\
\hline Eosinophilic, n (\%) & \multirow{3}{*}{17} & $10(58.82)$ \\
\hline Some eosinophilic some clear, n (\%) & & $3(17.64)$ \\
\hline Other types, n (\%) & & $4(23.52)$ \\
\hline
\end{tabular}


insulinoma, liver metastasis, and vascular and lymph node invasion as well as invasion to the splenic artery was observed in one patient. Vascular invasion was detected in three cases, vascular and lymphatic invasion in two cases and invasion to adjacent adipose tissue in one patient.

There was no relationship between tumor invasion and patient age (46 \pm 10.08 and $46.57 \pm 13.55$ years for those with and without invasion, respectively).

The mean tumor size in the invasive group was $2.85 \pm 1.70 \mathrm{~cm}$, which was significantly higher than the mean tumor size in the noninvasive group $(1.76 \pm 0.82 \mathrm{~cm})$.

There was no relationship between tumor location and tumor invasion. Also, the mean age of patients with tail tumors was higher than that of patients with the head and body tumors $(44.30 \pm 14.69,44.25 \pm 4.27$, and $52.54 \pm 11.48$ years for the head, body, and tail, respectively).

\section{Discussion}

This retrospective study reported on the clinicopathological characteristics of insulinoma in 43 patients. Insulinoma is the most common functional pancreatic NEN, as $76 \%$ of pancreatic NEN were insulinoma in a study by Cheng et al. (13). Insulinoma may occur in all ages, and there is no age limitation. However, the age of most patients is between 30 and 60 years, and the median age is in the fifth decade of life $(5,14)$. In the current study, patients ranged from 21 to 70 years of age, and most patients were aged below 50 years (28 patients/65.11\%) with a mean age of $45.4 \pm 13.3$ years, which is less than previous studies that reported insulinoma in the fifth decade of life $(5,13,14)$. However, the mean age of patients in the study by Peltola et al. (15) in Finland was 52 years, and in the study of Cheng et al. (13), 46 years, which is higher than in our study, while it was 39 years in the previous study in Iran, which is less than the current study (16). Insulinoma occurs in both genders without gender predominance or a slightly higher rate in the female gender $(5,14)$. In the present study insulinoma was observed in both genders, but more than half of the cases were female (65.11\%). However, the proportion of females in our study (65.11\%) was less than that in the Finnish study (70\%) (15). In contrast to the current study, in a previous study in Iran on 68 insulinoma cases, males slightly outnumbered females (53\% vs 47\%, respectively) (Table 2) (16).
The mean tumor size in the current study was $2.13 \pm 1.22 \mathrm{~cm}(0.6-5.5$ $\mathrm{cm})$, whereas in the previous study in Iran the mean tumor size was $2.9 \mathrm{~cm}(1-8.5 \mathrm{~cm})$ (Table 2) (16). However, tumor size in some previous studies was lower than in ours (14,17-19).

\section{Clinical Manifestations}

Due to high insulin levels, patients with insulinoma experience hypoglycemia symptoms that are categorized as either neuroglycopenic and neurogenic (catecholamine response) (20). These symptoms are improved by glucose administration (Whipple's triad) (8) and aggravated by fasting or exercise.

In the current study, both neurogenic and neuroglycopenic symptoms were seen in most insulinoma patients (81.39\%). In the study by Peltola et al. (15) in Finland, prevalence of neuroglycopenic and autonomic symptoms was $96 \%$ and $77 \%$, respectively. The rate of neuroglycopenic symptoms in that study (96\%) (15) was slightly higher than in ours (90.69\%). In the previous study in Iran, neuroglycopenic symptoms were observed in $97 \%$ of patients, which is higher than the current study, and adrenergic symptoms were observed in $89.6 \%$ of cases (16).

Insulinoma symptoms may occur in the postprandial state, in the fasting state, or even with no relationship to eating (21). In the present study, the majority of patients (88.37\%) showed symptoms in the fasting condition, and others showed symptoms in the postprandial or both conditions.

Weight gain in insulinoma occurs due to frequent eating to prevent hypoglycemic symptoms (22). In our study, $65 \%$ of patients experienced weight gain.

\section{Diagnosis}

The mean diagnosis delay in the present study was 2 years, while it was 13 and 15 months in Peltola et al. (15) and Cheng et al. (13), respectively which is less than in our study (15). However, the mean diagnosis delay in a previous study in our country was 39.9 months, which is higher than the one in the current study (Table 3) (16).

The presence of low plasma glucose associated with high serum insulin and C-peptide levels in a symptomatic patient is the basis for the biochemical diagnosis of insulinoma after exclusion of other causes of hyperinsulinemic hypoglycemia (23).

Table 3. Findings of our study compared to previous studies about insulinoma

\begin{tabular}{|l|l|l|l|l|l|l|}
\hline Study & $\begin{array}{l}\text { Number of } \\
\text { patients }\end{array}$ & Year & Mean age (year) & Sex (M/F), (n) & $\begin{array}{l}\text { Mean/median } \\
\text { diagnosis delay } \\
\text { (month) }\end{array}$ & $\begin{array}{l}\text { Mean tumor size } \\
\text { (cm) }\end{array}$ \\
\hline Current study & 43 & - & 45.4 & $15 / 28$ & 24 & 2.13 \\
\hline Peltola et al. (15) & 79 & 2018 & 52 & $24 / 55$ & 13 & - \\
\hline Yu et al. (14) & 17,9 & 2017 & 47,51 & $9 / 8,4 / 5$ & 11,1 & $1.5,2.1$ \\
\hline Iglesias et al. (19) & 29 & 2015 & 48.7 & $6 / 23$ & - & 1.7 \\
\hline Tsang et al. (18) & 36 & 2016 & 48.2 & $18 / 18$ & - & 1.47 \\
\hline Cheng et al. (13) & 76 & 2016 & 46.2 & $26 / 50$ & 24 & 3 \\
\hline Larijani et al. (16) & 68 & 2005 & 39 & $36 / 32$ & 40 & -2 \\
\hline Goh et al. (17) & 17 & 2009 & 50 & $7 / 10$ & 3 & 2.9 \\
\hline M: Male, F: female, MEN: multiple endocrine neoplasia & & & & 1.5 \\
\hline
\end{tabular}




\section{Imaging}

Due to the risk of developing diabetes following major pancreatic resection, pancreas-preserving surgery is the treatment of choice for insulinoma (20). Therefore, preoperative localization of the tumor is required for planning the appropriate surgical approach (24). However, without preoperative tumor localization, $10 \%-27 \%$ of insulinomas remain undetected during surgery (25).

In our study, in $22.5 \%$ (nine) of cases, imaging could not localize the tumor while in Finland study the tumor was not identified in nine cases (11\%) by imaging. This difference may be due to more imaging methods being used in that study compared with ours (15).

The sensitivity of EUS in tumor localization was $95.65 \%$ in our study, while it was $78 \%$ in Finland study (15). In that study EUS had the best sensitivity for detecting tumors less than $1 \mathrm{~cm}$ (15). Sensitivity of CT scan in tumor localization in Finland study was 51\%, and the mean sensitivity of CT scan in previous studies was $43 \%$, while in our study it was $68.18 \%$, which is higher than in previous studies $(15,26)$. In the study by Cheng et al. (13), the sensitivity of EUS and CT scan for the localization of pancreatic NEN was $100 \%$ and $91.5 \%$, respectively. In that study, abdominal ultrasonography, CT scan, MRI, and EUS were the most commonly used imaging modalities for preoperative localization of pancreatic NEN (13). Dynamic MRI, CT scan, and EUS are the most useful imaging modalities for the evaluation of insulinoma (27). The sensitivity of EUS is 70\%-95\%, which in combination with 3-phase CT scan, reaches $100 \%$ (27). As conventional sonography, CT scan, and MRI are commonly available modalities, they can be applied as first-line imaging methods for detection and localization of insulinoma (28). The success rate of tumor localization with a combination of intraoperative ultrasound and operative palpation reaches nearly $100 \%(29,30)$.

\section{Treatment}

In our study, $79.49 \%$ of patients underwent surgery, and $20.51 \%$ received medical treatment, while in the Finland study $90 \%$ of the patients underwent curative surgery and 3\% palliative surgery, which resulted in an overall rate of surgery higher than ours (15).

Lack of assessment of treatment outcomes in patients with insulinoma as well as limited access to data due to retrospective nature of the study were the main limitations of the current study that should be considered in future studies. Another limitation is the lack of detailed assessment of symptoms in each category.

\section{Pathology}

Most cases of insulinoma are benign, and approximately $10 \%$ of cases are malignant $(5,26)$. The diagnostic criteria for insulinoma malignancy include local invasion and lymph node or distant metastasis. Benign insulinomas are usually small and measure approximately $1-2 \mathrm{~cm}$ (31). In the present study, 7 cases (33.33\%) were identified as malignant insulinoma with invasion to adjacent tissues, while in a previous study in Iran, 5.8\% were malignant, which is lower than the percentage in our study (16). The rate of malignancy in our study is close to that of Yu et al. (14) (35\%), which is higher than that of Peltola et al. (15) (14\%).
In the current study, $80.95 \%$ of insulinoma tumors were grade 1 . In a study by Tsang et al. (18), $86.1 \%$ of tumors belonged to G1, which is higher than in ours while in a study by Yu et al. (14), 44.4\% of tumors were G1 which is lower than in ours. Also, according to Yu et al. (14), $44.4 \%$ of tumors were $\mathrm{G} 2$, while in our study this rate was $14.3 \%$.

According to Tsang et al. (18), 8.3\% of insulinomas were a component of MEN1 syndrome, while in our study, only in $2.32 \%$ of insulinoma cases was MEN1 syndrome diagnosed. In the previous study in Iran two cases of MEN1 syndrome (2.94\%) were identified, which is similar to the current study (Table 3) (16).

\section{Study Limitation}

Lack of assessment of treatment outcomes in patients with insulinoma as well as limited access to data due to the retrospective nature of the study were the main limitations of the current study that should be considered in future studies. Another limitation is the lack of assessment of symptoms in detail in each category.

\section{Conclusion}

This study presented the picture of insulinoma in the past decade in Iran. According to the results, the diagnostic delay of insulinoma has been reduced in our country during the past decade by improved imaging technologies but needs to be reduced further. For localization of insulinoma tumors, EUS and CT scan are the best modalities, while for size measurement, the accuracy of CT scan is greater than that of EUS. Also, it appears that the malignancy rate has increased in insulinoma tumors, and the tumor size has decreased compared with previous decades, probably due to the reduced diagnostic delay.

\section{Ethics}

Ethics Committee Approval: The study protocol was approved by the Ethics Committee at Imam Khomeini Hospital, and the study was conducted according to the Helsinki declaration (approval number: IR.TUMS.IKHC.REC.1396.3105, date: 07.08.2017).

Informed Consent: Retrospective study.

Peer-review: Externally peer-reviewed.

Authorship Contributions: Concept - N.S., M.H.; Design - N.S., M.H.; Data Collection or Processing - P.A., R.S., M.H.; Analysis or Interpretation - N.S., P.A.; Literature Search - P.A., M.H.; Writing - N.S., P.A., M.H.

Conflict of Interest: No conflict of interest was declared by the authors.

Financial Disclosure: The authors declared that this study received no financial support

\section{References}

1. Khagi S, Saif MW. Pancreatic neuroendocrine tumors: targeting the molecular basis of disease. Curr Opin Oncol 2015; 27: 38-43.

2. Fraenkel M, Kim MK, Faggiano A, Valk GD. Epidemiology of gastroenteropancreatic neuroendocrine tumours. Best Pract Res Clin Gastroenterol 2012; 26: 691-703.

3. Ito $\mathrm{T}$, Igarashi $\mathrm{H}$, Nakamura $\mathrm{K}$, Sasano $\mathrm{H}$, Okusaka T, Takano $\mathrm{K}$, et al. Epidemiological trends of pancreatic and gastrointestinal neuroendocrine 
tumors in Japan: a nationwide survey analysis. J Gastroenterol 2015; 50: 5864.

4. Boyar Cetinkaya R, Aagnes B, Thiis-Evensen E, Tretli S, Bergestuen DS, Hansen S. Trends in Incidence of Neuroendocrine Neoplasms in Norway: A Report of 16,075 Cases from 1993 through 2010. Neuroendocrinology 2017; 104: 1-10.

5. Zhao YP, Zhan HX, Zhang TP, Cong L, Dai MH, Liao Q, et al. Surgical management of patients with insulinomas: Result of 292 cases in a single institution. J Surg Oncol 2011; 103: 169-74.

6. Turaga KK, Kvols LK. Recent progress in the understanding, diagnosis, and treatment of gastroenteropancreatic neuroendocrine tumors. CA Cancer J Clin 2011; 61: 113-32.

7. Service FJ, McMahon MM, O’Brien PC, Ballard DJ. Functioning insulinoma-incidence, recurrence, and long-term survival of patients: a 60-year study. Mayo Clin Proc 1991; 66: 711-9.

8. Rostambeigi N, Thompson GB. What should be done in an operating room when an insulinoma cannot be found? Clin Endocrinol (Oxf) 2009; 70: 512-5.

9. Oberg K, Eriksson B. Endocrine tumours of the pancreas. Best Pract Res Clin Gastroenterol 2005; 19: 753-81.

10. Vaidakis D, Karoubalis J, Pappa T, Piaditis G, Zografos GN. Pancreatic insulinoma: current issues and trends. Hepatobiliary Pancreat Dis Int 2010; 9: 234-41.

11. Shin JJ, Gorden P, Libutti SK. Insulinoma: pathophysiology, localization and management. Future Oncol 2010; 6: 229-37.

12. Iglesias P, Díez JJ. Management of endocrine disease: a clinical update on tumor-induced hypoglycemia. Eur J Endocrinol 2014; 170: 147-57.

13. Cheng Y, Zhan H, Wang L, Xu J, Zhang G, Zhang Z, et al. Analysis of 100 consecutive cases of resectable pancreatic neuroendocrine neoplasms: clinicopathological characteristics and long-term outcomes. Front Med 2016; 10: 444-50.

14. Yu R, Nissen NN, Hendifar A, Tang L, Song YL, Chen YJ, et al. A Clinicopathological Study of Malignant Insulinoma in a contemporary series. Pancreas 2017; 46: 48-56.

15. Peltola E, Hannula $\mathrm{P}$, Huhtala $\mathrm{H}$, Metso S, Kiviniemi U, Vornanen M, et al. Characteristics and Outcomes of 79 Patients with an Insulinoma: A Nationwide Retrospective Study in Finland. Int J Endocrinol 2018; 2018: 2059481.

16. Larijani B, Aghakhani S, Lor SS, Farzaneh Z, Pajouhi M, Bastanhagh MH. Insulinoma in Iran: a 20-year review. Ann Saudi Med 2005; 25: 477-80

17. Goh BK, Ooi LL, Cheow PC, Tan YM, Ong HS, Chung YF, et al. Accurate preoperative localization of insulinomas avoids the need for blind resection and reoperation: analysis of a single institution experience with 17 surgically treated tumors over 19 years. J Gastrointest Surg 2009; 13: 1071-7.
18. Tsang YP, Lang BH, Shek TW. Assessing the short- and long-term outcomes after resection of benign insulinoma. ANZ J Surg 2016; 86: 706-10.

19. Iglesias P, Lafuente C, Martín Almendra MÁ, López Guzmán A, Castro JC, Díez JJ. Insulinoma: A multicenter, retrospective analysis of three decades of experience (1983-2014). Endocrinol Nutr 2015; 62: 306-13.

20. Hackert T, Hinz U, Fritz S, Strobel O, Schneider L, Hartwig W, et al. Enucleation in pancreatic surgery: indications, technique, and outcome compared to standard pancreatic resections. Langenbecks Arch Surg 2011; 396: 1197-203.

21. Vig S, Lewis M, Foster KJ, Stacey-Clear A. Lessons to be learned: a case study approach insulinoma presenting as a change in personality. J R Soc Promot Health 2001; 121: 56-61.

22. Marek B, Kajdaniuk D, Kos-Kudła B, Foltyn W, Borgiel-Marek H, Matyja V, et al. Insulinoma: diagnosis and treatment. Endokrynol Pol 2007; 58: 58-62.

23. Cryer PE, Axelrod L, Grossman AB, Heller SR, Montori VM, Seaquist ER, et al. Evaluation and management of adult hypoglycemic disorders: an Endocrine Society Clinical Practice Guideline. J Clin Endocrinol Metab 2009; 94: 709-28.

24. Guettier JM, Kam A, Chang R, Skarulis MC, Cochran C, Alexander HR, et al. Localization of insulinomas to regions of the pancreas by intra arterial calcium stimulation: the NIH experience. J Clin Endocrinol Metab 2009; 94 : 1074-80.

25. Grant CS. Insulinoma. Best Pract Res Clin Gastroenterol 2005; 19: 783-98.

26. Mehrabi A, Fischer L, Hafezi M, Dirlewanger A, Grenacher L, Diener MK, et al. A systematic review of localization, surgical treatment options, and outcome of insulinoma. Pancreas 2014; 43: 675-86.

27. de Herder WW, Niederle B, Scoazec JY, Pauwels S, Kloppel G, Falconi $M$, et al. Well-differentiated pancreatic tumor/carcinoma: insulinoma. Neuroendocrinology 2006; 84: 183-8.

28. Jensen RT, Cadiot G, Brandi ML, de Herder WW, Kaltsas G, Komminoth $P$, et al. ENETS consensus guidelines for the management of patients with digestive neuroendocrine neoplasms: functional pancreatic endocrine tumor syndromes. Neuroendocrinology 2012; 95: 98-119.

29. Taye A, Libutti S. Diagnosis and management of insulinoma: current best practice and ongoing developments. Research and Reports in Endocrine Disorders 2015; 5: 125-33.

30. Okabayashi T, Shima Y, Sumiyoshi T, Kozuki A, Ito S, Ogawa Y, et al. Diagnosis and management of insulinoma. World J Gastroenterol 2013; 19: 829-37.

31. B Baudin E, Caron P, Lombard-Bohas C, Tabarin A, Mitry E, Reznick Y, et al. Malignant insulinoma: recommendations for characterisation and treatment. Ann Endocrinol (Paris) 2013; 74: 523-33. 